\title{
The Effect of Accounting and Market Indicators on Predicting the Stock Prices for Jordanian Banks: An Econometric Study for the Period (2010-2015)
}

\author{
Suleiman Daood Al-Oshaibat ${ }^{1} \&$ Sufian Radwan Al-Manaseer ${ }^{1}$ \\ ${ }^{1}$ Faculty of Business, Tafila Technical University, Tafila, Jordan \\ Correspondence: Sufian Radwan Al-manaseer, Faculty of Business, Tafila Technical University, AT-Tafila, P. O. \\ Box 179, Tafila, 66110, Jordan. E-mail: sufian.r.manaseer@gmail.com
}

Received: November 21, 2017

Accepted: February 28, 2018

Online Published: March 15, 2018

doi:10.5539/ijef.v10n4p146

URL: https://doi.org/10.5539/ijef.v10n4p146

\begin{abstract}
This study aims at examine the ability of a group of financial ratios, which is derived from the financial statements of Jordanian commercial banks, to predict the prices of the market shares for the period (2010-2015). Besides, it investigates the explanatory power and the nature of the relation between some accounting and market indices, including compound and individual indicators, and the market share price. In order to achieve the objectives of this study, the researcher used the Panel Data and the time series data. While the Hussmann Test is used to choose the appropriate model whether it is a static effect modal or a random effect one based on Chi-Square probability value.

Throughout the discussion and the data analysis, the study highlights a set of results. One of the most important results shows that the effects of the independent variables as a single package on predicting the stock market prices were very strong.

In addition, the researcher comes up with some recommendations which emphasize the importance of disclosing the financial statements under study to investors and analysts periodically due to the importance of transparency in the financial sector. Moreover, while distributing earnings on participants, investors' preferences should be taken into consideration due to their influence on the share price since it is a futurist result of the investors' evaluations of the earnings distribution policy.
\end{abstract}

Keywords: market indicators, net income, dividend distributions, book value per-share, earning per-share, stock prices, Jordanian banks

\section{Introduction}

\subsection{Introduce the Problem}

The efficient financial market hypothesis states that if the financial market is efficient, its channels of communication will provide all stakeholders with equal access to financial information (Matar, 2009). An efficient market is also where; information is universally available to all investors at low cost, current security prices (debt as well as equity) reflect all relevant information and security prices only change when new information becomes available (Hill, 2010). In the financial market, there is an interaction between the financial data and the decision makers, where accounting disclosure plays an important role in enabling the market to perform efficiently. Therefore, information must be provided and presented to help investors in making their decisions according to the available information.

\subsection{Importance of the Problem}

This study aims to examine the ability of a group of financial ratios derived from various financial lists for the Jordanian banks to predict the stock prices, which is accordingly, can be used to formulate some of the goals, including:

a. Examine the explanatory power and know the nature of the relationship between the financial ratios and the stock price.

b. Find out the most important ratios related to the stock price. 
c. Construct a model on which can be depend in the process of forecasting stock prices of the Amman Stock Exchange, where the dependent variable is the stock price and the explanatory variables are a set of financial ratios that are important in the prediction of the stock prices.

\subsection{Relevant Scholarship}

There are most previous studies found a strong positive effect among stock price such as; The results of (Qutb's, 2004) study showed that there is a clear effect of the accounting data on stock prices for the GCC stock markets. It also showed that there are strong positive correlations among stock prices, book value per share, return on share, and the average price of shares and the rate of return on equity. Moreover, the results highlighted the difference in the impact of the combined accounting data on the prices of shares from one country to another.

In his study, Abu Hashish (2003) dealt with a set of quantitative variables, including earnings per share, market value, debt ratio and return on investment, where it is believed that they have an impact on the prices of shares in the ASE. The results of the study stressed that there is a set of variables that have a mutual relationship with the market price per share such as the earnings per share, market value to book value, equity ratio, alleged profit gain and return on assets.

The study of (Huwidi, 2000) aimed to test the ability of a group of indicators, which is derived from the accounting information and published for a group of companies listed in the Egyptian stock market as well as the market performance of these companies, to predict the expected return on investment in these shares. The study came up with a set of variables derived from the accounting information (share of distributions, rate of return on total assets, rate of return on equity and debt ratio) in addition to a range of market variables (trading volume and trading value).

In the study of (Tsoukalas \& Sil, 1999), Stock Price Determinants: A Certificate from the British Financial Market, the researchers aimed to determine the extended ability of the ratio for the dividends distributed to the stock market and the profit growth rate in predicting the market prices of traded shares in the British financial market, to serve the purpose of the study, a sample of companies listed in that market for the period 1995 January, 1996 December was studied. The two researchers concluded that dividend distributions are considered the main determinants of stock market prices and that the announcement of distributions increases the market value of shares.

The study of (Abdullah, 1995) targeted eight independent variables to discuss the determinants of share prices; the study found that the change in the shares of profits in the short term has an impact on the share prices, the return on equity, and on the general index of prices and government participation in the ownership of the company regardless the nature of activity, while the rest of the variables are no longer determinants of stock prices.

Also, the study of (haribeh \& Jafar, 1988) was about the effect of distributions and a number of financial indicators on the prices of shares in Jordanian public shareholding companies. The study showed that the financial indicators have a content that affects the returns on investment in public shareholding companies and consequently on the prices of their shares. The most important thing is the rate of return on the capital rate of return on equity and dividends,

Under the title, "Study: Profitability and Book Value of Shares", which is a scientific certificate from the Hong Kong Securities Market, (Peter Chen and Guochang Zhang) aimed to develop the view of stock market prices to show their effect on profits, returns and book value of shares. The researchers studied the ratio of returns on the ROE and book value for a sample of companies listed on the Hong Kong Stock Exchange. The researchers concluded that the relationship between profits and book value on the one hand and the market value of shares on the other is a positive, strong, and linear relationship.

\subsection{State Hypotheses and Their Correspondence to Research Design}

In order to achieve these objectives, the researcher tested the following hypothesis

The main hypothesis: Some of combined accounting and market indices is capable to predict the stock prices.

The first sub-hypothesis: The net income has the capability to predict the stock price

The second sub-hypothesis: The dividend distributions is capable to predict the stock price

The third sub-hypothesis: The book value per-share is capable to predict stock price

The fourth sub-hypothesis: The Earning per-share is capable to predict stock price. 


\section{Theoretical Framework}

Many studies have praised the importance of financial reports due to their information and their ability to predict stock prices. However, there have been differences in other studies. One of these differences have occurred because of the different tendencies and desires of investors and their ability to obtain the financial performance standards of the companies they wish to invest in, in addition to their explanatory ability and their beliefs in other variables and their ability to influence the stock price of the financial performance standards because of their disclosure confidence, where accounting disclosure plays an important role in enabling the market to perform efficiently. Thus, the information must be presented to help the investors make their decisions based on this type of information, which represents the goals of the company and does not have any accounting distortions. Accordingly, many of the studies considered that the accounting performance standards and the market indicators are explanatory and fundamental variables for clarifying and predicting various factors in companies such as the stock price and the ability of the company to increase its capital money through the issuance of shares to obtain the financial leverage at a lower cost.

The problem of the study lies on The importance of the financial reports on helping investors to make investment decisions, where the annual financial report considered as one of the most important and fundamental sources that provide investors, lenders, and other interested parties with the information they need to make important decisions (Abu Nassar \& Lotfi, 1998). Accordingly, finance lists are considered the most important part of the financial reporting segments that represent the main source of historical information about the outcome of the project activity during a certain period (Turki, 1993).

This study examines the importance of some financial ratios in the prediction process of stock prices for the Jordanian banks listed on the Amman Stock Exchange. Based on the importance of disclosure and financial transparency, the same information in influencing the decisions of investors and the stock prices and an extension of previous studies, the importance of financial and market ratios are essential in forecasting stock prices of the Jordanian banks listed on the Amman Stock Exchange during a specified period of time by determining some of the financial ratios in which the researchers believe they are related, and these financial ratios will be statistically tested to know their correlation coefficients and their explanatory power, and then determining their importance in predicting stock prices.

Consequently, the study will answer the following questions:

Are the following market indicators (Net Income, Dividend Distribution, Book Value Per Share, Earning Per Share) capable to predicting the stock prices.

\section{Methodology}

The study depended on the analytical method through doing the statistical analysis of the independent variables on the dependent variable related to the subject of the study in order to cover the analytical part of the study, in addition to the descriptive method through relying on books, periodicals, previous studies and financial reports of the banks of the study' sample, whether the direct or the indirect ones, to cover the theoretical part.

The six-year study period was used to demonstrate the importance of these financial and market indicators to predict the stock prices.

The population of the study includes all the Jordanian banks listed on the Amman Stock Exchange. The sample of the study consists of the Jordanian public shareholding banks. However, some banks will be excluded for the following reasons:

1) Foreign banks due to the lack of data.

2) Banks traded in the second market.

\subsection{The Study Variables}

- Independent Variables:

(X1): Net income: the results of the Bank's operations during the fiscal year after taxes + Market variables for stock. (Matar,2009)

(X2): Dividend distributions (DPS), which is measured by dividing the profits distributed on the subscribed shares. This share is determined after subtracting the preferred shares from the declared dividends for distribution (Matar, 2009).

(X3): Book value per share, This index will be used in the decision-making related to buy shares, which is the net ordinary shareholders' equity divided by the number of ordinary shares registered on the balance sheet date 
(Matar, 2009).

(X4): Earnings per share (EPS) is calculated by dividing the profits available after tax by the number of shares subscribed. This index, some call the share of profits, is used mainly to assess ordinary earnings per share due to its importance to investors in financial markets. And the accounting standards issued by accounting professional councils, including Accounting Standard (33), on the need to present the comparative value of this indicator, ie, EPS, in the income statement (Matar, 2009).

- Dependent variable: (Y): stock prices

\subsection{Study Model}

The panel data analysis, the data of time series cross-selection data time, where Hsiao (1986) explained that a long analysis of data is characterized as taking into account individual differences, and provide more useful data and varied and less link between the variables and a large number of the freedom degrees, which are more effective than the time series that suffer from the problem of self-correlation. The first table of data has the ability to define and measure the effects that are not observed in the descriptive analysis. The (Baltagi, 2000) time series and the adopted model is:

$$
Y i t=a X i t+U i t
$$

whereas:

Yit: dependent variable;

Xit: Independent variables;

Uit: Random error or unspecified error limit "Woral and pratt 2000".

In the analysis of the tabular data, the fixed effects model, which has a constant tendency over time, is used. The constant limit reflects the characteristics of the units being tested, which are different from one unit to another, and the random effects model, which also has a constant tendency over time. And this randomization is a function in the average values plus the random limit (Manez, Rochina, \& Sanchis, 2004).

In order to test the appropriate model, the model of static effects or the model of random effects, the Hausmann test was used, based on the value of the Chi-square relative to the moral level. If the value is less than 5\%, the fixed effects model is used. And if the value is greater than 5\%, the Torres-reyna 2007 random effects model, he E-views 7 software, was used to test the study models.

\section{Results and Discussion}

The main hypothesis: Some of combined accounting and market indices is capable to predict the stock prices.

I shows that some of the combined accounting and market indices are able to predict the stock prices, and the results were as follows:

$$
\mathrm{Y}=1.70+0.030213 \mathrm{X} 1+7.92 \mathrm{E}-09 \mathrm{X} 2+5.215476 \mathrm{X} 3+5.34 \mathrm{E}-05 \mathrm{X} 4
$$

\begin{tabular}{|c|c|c|c|}
\hline \multicolumn{4}{|l|}{ Dependent Variable (Y) } \\
\hline P-Value (Probability) & T-Test & Coefficient & Variables \\
\hline 0.0000 & 8.752487 & 1.700423 & $\mathrm{Y}$ \\
\hline 0.0000 & 4.512448 & 0.030213 & $\mathrm{X} 1$ \\
\hline 0.0008 & 3.571671 & 7.92E-09 & $\mathrm{X} 2$ \\
\hline 0.0010 & 3.522849 & 5.215476 & $\mathrm{X} 3$ \\
\hline 0.9997 & 0.000387 & $5.34 \mathrm{E}-05$ & $\mathrm{X} 4$ \\
\hline Chi-sq Statistic: 38.54 & \multicolumn{3}{|l|}{ Probability: 0.000} \\
\hline \multicolumn{4}{|l|}{$\mathrm{R}^{2}: 98.7 \%$} \\
\hline \multicolumn{4}{|l|}{ Adjusted $\mathrm{R}^{2}: 98.41 \%$} \\
\hline \multicolumn{4}{|l|}{ F-Statistic: 282.92} \\
\hline \multicolumn{4}{|l|}{ Probability: 0.0000} \\
\hline DW Test: 1.88 & & & \\
\hline
\end{tabular}

Table 1. Results of testing the study's main hypothesis

X1: Net Income, X2: Dividend distribution, X3: Book value per share, X4: Earning per share, Y: Stock prices. 
The results of the Husman test showed that the estimation should be taken according to the model of constant effects where the probability or moral level was less than $5 \%$ for the chi-square according to table (1) above. It is also noted that the coefficient of some accounting and logistic indicators combined is always positive and has statistical significance for predicting prices market shares where the adjusted R-SQUARED coefficient interprets ( $98.41 \%$ of the changes in the independent variables and the statistical "F-statistic" was 282.9 with a probability of 0.000 and the coefficient of "Durbon-watson" was 1.88 which means the significance of the model.

based on the above results For some accounting and logistic indicators predictive power With prices reaching the value of " 1.7 " which means that the relationship between them is positive.

The first sub-hypothesis: The net income has the capability to predict the stock price

The results were as follows:

$$
\mathrm{Y}=2.536222+0.043739 \mathrm{X} 1
$$

Table 2. Results of testing the study's first sub-hypothesis

\begin{tabular}{llll}
\hline $\begin{array}{l}\text { Dependent Variable (Y) } \\
\text { Method: Panel Data }\end{array}$ & & & \\
\hline P-Value (Probability) & T-Test & Coefficient & Variables \\
\hline 0.2137 & 1.257270 & 2.536222 & Y \\
0.0612 & 1.908935 & 0.043739 & \\
\hline Chi-sq Statistic: 0.019812 & Probability: 0.8881 & & \\
$\mathrm{R}^{2}: 0.076889 \%$ & & & \\
Adjusted $\mathrm{R}^{2}: 0.0609 \%$ & & & \\
F-Statistic: 4.831 & & & \\
Probability: 0.031957 & & & \\
DW Test: 1.258312 & & & \\
\hline
\end{tabular}

X1: Net Income, Y: Stock prices.

The results of the Husman test showed that the estimated should be according to the model of random effects where the probability or moral level was more than $5 \%$ for the chi-square according to table (2) above. It is also noted that the net income factor is always positive to predict stock prices and is not significant the mean R-SQUARED coefficient explains only $0.0609 \%$ of the changes in the independent variables. The "F.-statistic" statistic was 4.833 with a probability of 0.0319 and the Durbon-watson coefficient was 1.258 which means that the model is not significant.

Note that the relationship between net income and its capability to predict the stock price reached 0.043739 , which means that the relationship between them is positive and weak.

The second sub-hypothesis: The dividend distributions is capable to predict the stock price the results were as follows:

$$
\mathrm{Y}=2.200977+1.47 \mathrm{X} 2
$$

Table 3. Results of testing the study's second sub-hypothesis

\begin{tabular}{lccc}
\hline $\begin{array}{l}\text { Dependent Variable (Y) } \\
\text { Method: Panel Data }\end{array}$ & & & \\
\hline \multicolumn{1}{c}{ P-Value (Probability) } & T-Test & Coefficient & Variables \\
\hline 0.000 & 1.34789 & 2.200977 & Y \\
0.000 & 7.067838 & $1.47 \mathrm{E}-08$ & $\mathrm{X} 2$ \\
\hline Chi-sq Statistic: 54.20 & Probability: 0.000 & & \\
$\mathrm{R}^{2}: 97.97 \%$ & & & \\
Adjusted $\mathrm{R}^{2}: 97.56 \%$ & & & \\
F-Statistic: 237.099 & & & \\
Probability: 0.000 & & & \\
DW Test: 1.5288 & & & \\
\hline
\end{tabular}

X2: dividend distributions, Y: Stock prices. 
The results of the Husman test showed that the estimate should be according to the model of constant effects where the probability or moral level was less than $5 \%$ for the Chi-squired according to Table (3) above. It is also noted that the coefficient of the dividend distribution is always positive and the modified R-SQUARED coefficient interprets $97.56 \%$ of the changes in the independent variables and the "F-statistic" statistic was 237.099 with a probability of 0.00 and the Durbon-watson coefficient was 1.5288 which means the significance of the model.

It is also noted that the relationship between the dividend distributions and their capability to predict stock prices reached 2.200977, which means that it is positive and strong.

The third sub-hypothesis: The book value per-share is capable to predict stock price

the results were as follows:

$$
\mathrm{Y}=2.209118+5.26359 \mathrm{X} 3
$$

Table 4. Results of testing the study's third sub-hypothesis

\begin{tabular}{|c|c|c|c|}
\hline $\begin{array}{l}\text { Dependent Variable (Y) } \\
\text { Method: Panel Data }\end{array}$ & & & \\
\hline P-Value (Probability) & T-Test & Coefficient & Variables \\
\hline 0.000 & 12.055 & 2.209118 & $\mathrm{Y}$ \\
\hline 0.046 & 2.97079 & 5.26359 & $\mathrm{X} 3$ \\
\hline Chi-sq Statistic: 14.7615 & Probability: 0.0001 & & \\
\hline \multicolumn{4}{|l|}{$\mathrm{R}^{2}: 98.01 \%$} \\
\hline \multicolumn{4}{|l|}{ Adjusted $\mathrm{R}^{2}: 97.61 \%$} \\
\hline \multicolumn{4}{|l|}{ F-Statistic: 242.41} \\
\hline \multicolumn{4}{|l|}{ Probability: 0.000} \\
\hline DW Test: 1.5678 & & & \\
\hline
\end{tabular}

The results of the Husman test showed that the estimation should be according to the model of constant effects where the probability or moral level was less than $5 \%$ for the Chi-squired according to table (4) above. It is also noted that the coefficient of book value is always positive and the modified R-SQUARED coefficient interprets $97.61 \%$ of the changes in the independent variables and the "F-statistic" statistic was 242.41 with a probability of 0.000 and the "Durbon-watson" was 1.567 which means the significance of the model.

The correlation between book value and its capability to predict stock prices has also reached a value of 2.209118, which means it is positive and strong.

The fourth sub-hypothesis: The Earning per-share is capable to predict stock price

the results were as follows:

$$
Y=2.219358+1.87495 X 4
$$

Table 5. Results of testing the study's fourth sub-hypothesis

\begin{tabular}{lcll}
\hline $\begin{array}{l}\text { Dependent Variable (Y) } \\
\text { Method: Panel Data }\end{array}$ & & & \\
\hline P-Value (Probability) & T-Test & Coefficient & Variables \\
\hline 0.000 & 0.372064 & 2.219358 & Y \\
0.0373 & 0.879157 & 1.878495 & $\mathrm{X} 4$ \\
\hline Chi-sq Statistic: 2.883476 & Probability: 0.0895 & & \\
$\mathrm{R}^{2}: 0.087442 \%$ & & \\
Adjusted $R^{2}:-0.015866 \%$ & & & \\
F-Statistic: 0.846418 & & & \\
Probability: 0.540087 & & & \\
DW Test: 0.181688 & & & \\
\hline
\end{tabular}

X4: Earning per-share, Y: Stock prices. 
The results of the Husman test showed that the estimate should be according to the model of random effects where the probability or moral level was greater than $5 \%$ for the Chi-squired according to table (5) above. It is also noted that the EPS coefficient is always positive but not statistically significant for prediction (R-SQUARED). The adjusted R-SQUARED coefficient explains $(-0.015866 \%)$ of the changes in the independent variables and the statistical "F-statistic" was 0.846 with a probability of 0.54 and the Durbon-watson coefficient was 0.181688 which means that the model is insignificant.

There is a relationship between earnings per share and its capability to predict stock prices.

\subsection{Results}

We obtain the following results:

1) There is a statistically significant relationship between some accounting and market indices combined to predict the stock prices, (net income, dividends distribution, book value per-share, earning per-share) as independent variables on the stock price.

2) There is no statistically significant relationship between net income as an independent variable and the stock price as a dependent variable.

3) There is a statistically significant relationship between the book value per-share as an independent variable and the stock price as a dependent variable.

4) There is a statistically significant relationship between the dividend distributions as an independent variable and the stock price as a dependent variable.

5) There is no statistically significant relationship between earnings per-share as an independent variable and the stock price as a dependent variable.

\subsection{Recommendations}

1) The commercial banks in Jordan should take into account the importance of the role of disclosure of financial and market indicators on investment decisions of the investor and achieve efficiency in the market if possible.

2) The need to disclose these data to investors and local periodically on the importance of transparency in the financial sector.

3) When starting the process of distributing dividends to shareholders, it is necessary to pay attention to investors 'preferences, which will affect the stock price as a result of investors' future valuations of the profit distribution policy.

4) Investors need to be aware of the feasibility and importance of these indicators.

\section{References}

Abdullah, A. Q. (1995). Specific returns for share companies' share prices in Saudi Arabia. Yarmouk Research Journal, 11(1), 135-155.

Abu, H. (2003). The role of published accounting information in the prediction of stock prices in the Stock Exchange in the Hashemite Kingdom of Jordan: Applied study. Al-Basaer, 7(2), 151-194.

Abu, N. M., \& Mounir, L. (1998). Factors Affecting the Delay in Issuing the Annual Financial Reports of Jordanian Companies. Journal of Administrative Studies, 2.

Al-Saaydeh. (1996). The Ability of Accounting Information on the Interpretation of the Market Value of shares of Jordanian Public Shareholding Companies. Al-Manarah, 1, 153-183.

Baltagi, B. H. (2000). Econometric analysis of panel data (2nd ed.). NewYork: John Wiley \& Sons.

Collins, D. W., \& Kothair, S. P. (1980). The importance of cross-sectional determinants of response (pp. 3-28).

Ghraibeh, \& Jafar. (1988). The content of accounting figures of information in Jordanian joint stock companies. Yarmouk University. Yarmouk Journal, 4(2), 202-233.

Hsiao, C. (1986). Analysis of panel data. Cambridge UK: Cambridge university Press.

Huwidi. (2000). Analysis of the relationship between published accounting information and expected return on Shares traded in the Egyptian stock market. The Scientific Journal of Economy and Trade, 9.

Manez, J. A., Rochina, M., \& Sanchis, J. A. (2004). The Decision to Export: A panel data analysis for Spanish Manufacturing. Applied Economics Letters, 11, 669-673. https://doi.org/10.1080/1350485042000236601

Matar, M. (2009). Investment Management, Theoretical Framework and Practical Applications (5th ed.). Dar 
Wael For Publishing and Distribution, Jordan.

Peter, C., \& Grouching, Z. (2004). Profitability, earnings and book value in equity valuation: A geometric view and empirical evidence. Hong Kong University of Science and Technology, 1-4.

Published annual financial reports of the commercial banks under study (2010-2015).

Quteb, A. S. (2004). Comparative Analysis of the Relationship between Accounting Data and Share Prices in the GCC Countries. Faculty of Commerce, Cairo University. Journal of Accounting, Management and Insurance, (64), 40-78.

Robert, A. H. (2010). Portfolio theory \& financial Analyses (1st ed).

Schadewwitz, H. J., Kanto, A. J., \& Kahra, B. (2002). An analysis of the impact of varying levels of interim disclosure on Finish share prices within five days of the announcement. American Business Review, 33-45.

Torres-Reyna, O. (2007). Panel data analysis fixed and random effects using STATA. Princeton university.

Tsoukalas, Dimitrios, Sil, \& Shomir. (1999). The Determinants of Stock Prices: Evidence from UK Stock Market. Management Research News, 22(5), 1-5. https://doi.org/10.1108/01409179910781652

Turki, M. I. (1993). Analysis of Financial Reports. King Saud University, Deanship of Libraries, Riyadh, Saudi Arabia.

Worrall, L. J., \& Pratt, C. T. (2004). Estimation issues associated with time series cross section analysis in criminology. Western Criminology Review, 5(1), 35-49.

\section{Copyrights}

Copyright for this article is retained by the author(s), with first publication rights granted to the journal.

This is an open-access article distributed under the terms and conditions of the Creative Commons Attribution license (http://creativecommons.org/licenses/by/4.0/). 